\title{
Built Environment Professionals Awareness Towards Crime Prevention Criteria In Malaysian Housing Development
}

\author{
Ilias Said \& Radzi Ismail \\ School of Housing, Building and Planning, Universiti Sains Malaysia, Malaysia \\ Corresponding author: ilias@usm.my, radzi@usm.my
}

Article History: Received:11 January 2021; Accepted: 27 February 2021; Published online: 5 April 2021

\begin{abstract}
The crime rates increase yearly concurrent with the growth of the Malaysian population. Without considering the comfortable and safe environment during the pre-development stage, housing development will increase the Malaysian crime rate. The built environment professionals know well the crime prevention criteria that should consider by housing developers. This paper examines the relationship between crime prevention criteria and awareness of built environment professionals in Malaysian housing development. The crime prevention criteria are layout design, building design, parking, access and walkways, landscape and urban design elements, lighting, safety equipment, management and maintenance, community and occupant attitude. The data collection chose quantitative methodology. In total, 191 built environment professionals working with developers registered under the Real Estate and Housing Developers Association of Malaysia (REHDA) were involved in this study. In total, the further analysis used 191 sets of questionnaires. This study's main findings are the lighting and occupant attitude significantly contribute to crime prevention that built environment professionals considered to implement in Malaysian housing.
\end{abstract}

KEYWORDS: Crime prevention, built environment professionals, criteria, housing development

\subsection{INTRODUCTION}

Nowadays, a comfortable and safe environment became the main thing that housing developer should consider during the pre-development stage to provide the best product for their customers. Therefore, the built environment professionals should consider comfort in their housing development, improving living standards, including health, safety, and convenience (Robin, 2017). According to Shafii and Miskam (2011), quality of life is essential by knowing that a country's people need a comfortable living standard. Perfection in life was the beginning of a prosperous life. Housing is a critical component for developing nations economically, bringing the government's policy to implement housing development.

The basic need for the human is food, clothing and shelter. Everyone also has the right to fulfil their values and aspirations as an individual (UNDP, 2013). However, the world's population is also affected by population growth, such as the impact on land use, poverty, and economic injustice (Sernau, 2009). The fifth strategic thrust in the Tenth Malaysia Plan (RMK10: 2011-2015) included providing a conducive environment towards improving the quality of life. Housing as a basis for the well-being of the people. The government intends to provide enough affordable houses to all Malaysian residents through this core, especially to the low-income group. Simultaneously, the strengthen and enforced regulations ensure that decent and affordable housing can be built (JPM, 2016). It is to ensure the housing areas in a comfortable and safe environment (Zulkepli, 2011). The government attempts to provide the completed facilities in ensuring the residents are comforts. Furthermore, in the Eleventh Malaysia Plan (RMK11: 2016-2020), the demand for affordable houses by low-income groups remain high and supported by Government initiatives such as 1Malaysia People's Housing (PR1MA) Rumah Idaman Rakyat and Rumah Mesra Rakyat. It is central to the company's strategy to improve people's well-being (JPM, 2016).

Positive or negative of residents influenced by housing development perfection aspects. As a whole, the housing environment area became the catalyst of life well-being for the residents. According to Sukimin (2008), the housing area's physical and social factors affected residents' well-being, such as the safety aspect of design, orderly home interior, and a well-maintained exterior. As mention by Bujang et al. (2010), the quality of housing involves physical and non-physical, for physical aspect are position, design and type of house and the comfort of residents.

Meanwhile, the non-physical aspect involves the economy, population and number of crimes in that area. The quality of housing influenced the life well-being of residents. The imperfection of housing affected the quality of residents' lives in terms of owner satisfaction, family health, children's academic achievement, family relationship, and others. Besides, the house size was not suitable for the family size in a house will influence the comfort and affect the family relationship (Junaidi, 2015). Fadzil (2013) also stated that the position or location factor would exploit the potential house buyers on their purchasing decision, such as distance from working place and other 
necessary facilities. The construction industry is critical to Malaysian residents, contributing to producing housing to fulfil the requirements (Musa, 2016). Housing development growth very fast in concurrent with the demand.

Remarkably, the growth of urban housing creates many benefits to the national economy, but at the same time, it is often becoming criminal targets. Indirectly, therefore, insecurity and anxiety are created among residents at the level of public safety. These conditions have affected the physical and emotional quality of life of society (Mustaffa, 2007). Criminal issues in the urban area caused the alarm and fear of the city's residents - housing developments. Therefore, apply to the concepts of crime prevention. These concepts have successfully demonstrated that it reduces the number of criminal cases. Othman (2007) noted that housing development that implemented crime prevention concepts would lessen the threat of crime and provide a safe environment for residents.

The built environment professionals know well the crime prevention criteria that should implement in Malaysian housing development. Their awareness well improved the quality of life and comfort of residents by producing a safe environment. This paper examines the relationship between crime prevention criteria and understanding of built environment professionals in Malaysian housing development.

\subsection{LITERATURE REVIEW}

Crime refers to the misbehaviour of individuals or groups towards the prohibited and illegal in a country, and it can threaten society's safety and well-being in certain areas. Essential things in life can stay in any place without interference or safely from anything. According to Leh (2017), security refers to unthreatened businesses that provide well-being and peace.

Malaysia's primary goal is to improve its security and reach a development level in a crime rate reduction. One case of the social problem and one is hardly the causes of another, but criminal cases' accumulation caused issues to generate fear and anxiety. A significant percentage of crime victims are affected physically and emotionally, especially those who suffer a blow to their bodies or mental health. as mentioned by Johar and his colleagues (2017), crime has a large and lasting effect on the national economy

The slogan of prevention founded the concept of a safe city is better than the elimination of crime (JPBD, 2010). There is a substantial correlation between crime prevention strategies that incorporate environmental design and crime-reduction. By imposing conditions on the offender so that the individual has no choice but to comply with the terms of the punishment, The opportunity to criminal will caused the unplanned series of crimes to occur (JPBD, 2010).

In the housing development, built environments professionals should consider crime prevention aspects from the beginning of the project to ensure they will produce good houses and provide a safe environment for their customers. Crime prevention consists of ten criteria. These criteria are layout design, building design, parking, access and walkways, landscape and urban design elements, lighting, safety equipment, management and maintenance, community and occupant attitude.

\section{Layout Design}

According to Latif et al. (2017), the relationship between building design and other aspects such as road location, lanes, and corridors will ensure that area's safety. Minimal road and alternative routes increase the level of housing safety. As mentioned by Newman (1972), limited space but multi-purpose will ensure that area crimes free. User observation will maximize when more open room and the blind area like corners targeted by criminals were more comfortable to discover. According to Latif et al. (2017), the limited route will make the criminals challenging to escape when committing the crime in the area and intensify their anxiety.

\section{Building Design}

According to Newman (1972), the building design and community should consider during pre-development, contributing to natural surveillance. These factors essential in detecting and preventing crime that occurs in the housing area. Whenever the house's design does not cater to the family needs, it can lead to social crime activities such as vandalism (Pauzi, 2017). If the house design inappropriate and has a lot of blind areas contribute to the criminal's opportunity.

\section{Parking}


As stated in parking guidelines, car park design should provide adequate and bright lighting (JPBD, 2011). These safety features become regular practices to authorities all over the world. Right lighting conditions create a safer and crime-free environment (Smith, 1996). Other safety features, such as CCTV, emergency exit signs and emergency buttons, should be considered at a strategic location, as indicated in the Crime Prevention Through Environmental Design (CPTED) concept. This safety features aids in reducing the criminal opportunity in the housing area, and it became essential that built environment professionals need to consider it.

\section{Access and Walkways}

The residential area's direct access is the automatic barrier gate with facilities of the guardhouse, and it surrounded by a fence. The management gives an impressive pass-in and pass-out device to prevent the criminals from leaving the neighbourhood. All the occupants need to display residential stickers for each of their vehicles (Othman, 2007). Most residential in Malaysia have access and exit card for their occupant, reducing the opportunity of crime. The appropriate design and maximum use of roads were essential to access and walkways in the residential area.

The pedestrian walkway rarely used In the residential area. Without proper courtesy from the resident's management, that place will not become the targeted area for criminals and misused, and it should revitalize the surrounding environment (Ali, 2006). Crime prevention within the compound is achieved through adequate lighting to help prevent crime.

\section{Landscape and Urban Design Elements}

According to Jabatan Lanskap Negara (2008), the landscape is a prominent interaction place for everyone. The landscape shows the shape of soil geology, ecology, the pattern of human activities, etc. This area became the primary interaction between natural and human needs, and it also highlights the beauty and aesthetic value. The landscape consists of two categories, namely soft landscapes and challenging landscapes (Meinig, 1979). The delicate landscape is an elemental of plants or natural, which encompass the various type of tree.

However, the complex landscape demands professional standards of thoroughness, patience, drive, and tenacity in handling the inquiries, day-to-day demands, consistency, and humility in handling everyday matters. Most urban places have challenges related to constructs and materials such as buildings, benches, tables, and street signs. Ali claims that 8 feet are the absolute maximum height for a tree. Trees should be under surveillance to prevent them from becoming an escape route of illegal activity. These include hard and soft landscapes such as parks, garden tables, etc. As mentioned by Ali (2006), the high of planted trees should not exceed 7 feet. All the planted trees should be well cared for and maintain to avoid them become hideout place for criminals.

\section{Lighting}

The blind area was criminals targeted place to do their illegal activities. The quality lighting can recognize the human face through a normal vision at a distance of 15-25 meters. This quality lighting will effectively support the CCTV to detect the criminals. According to Latif et al. (2017), safety equipment such as safety mirror and warning signs can be enhanced through good lighting, thus reducing crime. Improving the quality of lighting can reduce crime (Clarke, 2008). Concurrently, it will also bring the community together.

\section{Safety Equipment}

Zinalibdin and Lyndon (2016) stated other factors contributing to criminal behaviour are physical factors that unsatisfactory environment conditions like low street lighting, no CCTV, etc. Preparedness with adequate safety equipment contributed to reducing the crimes in the housing area. The housing area with CCTV equipment provide early warning to criminals, and it also will be used to obtain images to detect and arrest criminals (Leh, 2017). The most important thing is that all the safety equipment should achieve standard quality and well function.

\section{Management and Maintenance}

The municipal manager is responsible for managing maintenance work in a residential area (Yusoff et al., 2011). All multi-unit dwellings were subject to the Multi-unit housing construction provisions specified in the Strata Titles Act of 1985. Therefore, it was responsible for all matters of management and maintenance of the joint property. However, under Act 318, the Management Municipality can appoint any qualified firm to carry out maintenance. According to Zinalibdin and Lyndon (2016), Municipal Management's housing areas do not adequately maintain social problems such as vandalism, etc. It indicates the sign of social issues and community failures. With efficient and systematic management and maintenance, monitoring, and criminal activities occur 
in the housing area (Othman, 2007). Well, the function of municipal government ensures the safe environment of the housing area.

\section{Community}

Most citizens strive to have meaningful daily lives. Promoting healthy community relations and housing complex will improve the management of the inhabitants' lives (Othman, 2007). Social organization in Malaysian residential such as Kawasan Rukun Tetanga (KRT) and Skim Rondaan Sukarela (SRS), has improved the resident's relationship and encourage a sense of belonging. Security in the residential area was not only under police responsibility, but it also shared responsibility between the community and residents. The enhancement of community activities will monitor and control crime rates. According to Mustaffa et al. (2013), the residents should be giving continuous commitment to community activities, and it provides a safe environment in their residential area. The community was a backbone of social improvement in providing harmonize nation and reducing crimes.

\section{Occupant Attitude}

According to Pauzi (2017), brittle relationship and dullness among neighbour will increase the crime rates. The housing area's essential thing is that the residents should be responsible for caring for their neighbours. Jacobs (1961) stated that community awareness was related to local communities' active involvement in protecting their housing area from criminals' threat and not relying on police surveillance. The essential is occupants' attitude towards the safe environment in the housing area by involving in community activities, and knowing each other will avoid criminals' threat.

\subsection{METHODOLOGY}

In this study, the quantitative method was chosen as a technique of data collection. According to Kreuger and Neuman (2006), quantitative research begins with selecting the topic to be studied and usually, this approach looking to the general study area or professional issues. The chosen samples must represent the study population, and the results can provide a comprehensive interpretation (Omar et al., 2010). This study used stratified random sampling. Stratified random sampling involves the process of segregation and separation into strata or groups, then selecting the simple random for each of these layers (Bougie and Sekaran, 2009).

This study's sample consists of built environment professionals directly involved in housing development in Peninsular Malaysia and registered with the Real Estate and Housing Developers Association of Malaysia (REHDA). In total, the further analysis used 191 sets of questionnaires,

\subsection{RESULTS AND DISCUSSION}

The relationship between crime prevention criteria was studied by multiple regression (layout design, building design, parking, access and walkways, landscape and urban design elements, lighting, safety equipment, management and maintenance, community and occupants' attitudes) and built environment professionals awareness in Malaysian housing development. This study used a significant level at $\mathrm{P}=0.005$, as suggested by Sekaran (2003).

Table 1 shows the results of multiple linear regression analysis. The analysis results found no significant relationship between layout design and crime prevention awareness among built environment professionals with values $(\mathrm{P}=0.218>0.05)$. The value of $\mathrm{P}$ is greater than the significant level. This finding shows that the layout design was not substantial to implement as crime prevention for Malaysian housing.

For building design, the results show that the value of $\mathrm{p}=0.144$ was greater than the significant level of 0.05 . There was no meaningful relationship between building design and crime prevention awareness among built environment professionals in Malaysian housing. This finding not supported Fauzi (2017) study.

Meanwhile, the relationship between parking and crime prevention awareness among built environment professionals was not significant, which the value of $\mathrm{P}=0.255$ was greater than the significant level at 0.05 .

The results of the relationship between access and walkway and crime prevention awareness among built environment professionals also not significant, which the value of $\mathrm{P}=0.064$ was greater than the significant level at 0.05 . This finding also not supported Ali (2006) study.

The relationship between landscape and urban design elements and crime prevention awareness among built environment professionals also not significant, which the value of $\mathrm{P}=0.074$ was greater than the significant level 
at 0.05 . This finding also shows the negative relationship that could shrink other results not based on built environment professionals' awareness.

Meanwhile, the relationship between lighting and crime prevention awareness among built environment professionals was significant, which the value of $\mathrm{P}=0.009$ and the significant level at 0.05 . These results supported the previous finding from Clarke (2008) and Latif et al. (2017). It shows that the built environment professionals in Malaysian housing more concern with basic things that contributed to reducing the blind area.

Next, the relationship between management and maintenance and crime prevention awareness among built environment professionals was not significant, which the value of $\mathrm{P}=0.344$ and the significant level at 0.05 . These results have not supported the previous findings.

The results of the relationship between community and crime prevention awareness among built environment professionals also not significant, which the value of $\mathrm{P}=0.994$ was greater than the significant level at 0.05 . These results did not support the previous findings.

Meanwhile, the relationship between occupant attitude and crime prevention awareness among built environment professionals was significant, which the value of $\mathrm{P}=0.0042$ and the significant level at 0.05 . These results supported the previous finding from Pauzi (2017) and Jacobs (1961). These findings proved that the occupant attitude determines the crime rates in their residential area.

Table1: Regression Analysis of the Relationship between Crime Prevention Criteria and Crime Prevention Awareness of Built Environment Professionals

\begin{tabular}{|l|c|c|c|}
\hline \multicolumn{1}{|c|}{ Crime Prevention Criteria } & Std Beta & \multicolumn{1}{c|}{$\mathrm{t}$} & Sig. $\mathrm{p}$ \\
\hline Layout design & 0.137 & 1.237 & 0.218 \\
\hline Building design & 0.064 & 0.767 & 0.444 \\
\hline Parking & 0.112 & 1.143 & 0.255 \\
\hline Access and walkways & -0.188 & -1.862 & 0.064 \\
\hline Landscape and urban design elements & -0.177 & -1.798 & 0.074 \\
\hline Lighting & 0.243 & 2.634 & 0.009 \\
\hline Safety equipment & 0.068 & 0.755 & 0.451 \\
\hline Management and maintenance & 0.091 & 0.948 & 0.344 \\
\hline Community & 0.001 & 0.008 & 0.994 \\
\hline Occupant attitude & -0.179 & -2.044 & 0.042 \\
\hline
\end{tabular}

Based on Figure 1, overall, there were only two variables, namely (1) lighting and (2) occupant attitude was significant factors in influencing the crime prevention awareness among built environment professionals in Malaysian housing development. The multiple linear regression analysis results suggest that Malaysian developers need to consider the lighting and occupancy attitude in providing safe housing based on the built environment professionals' awareness.

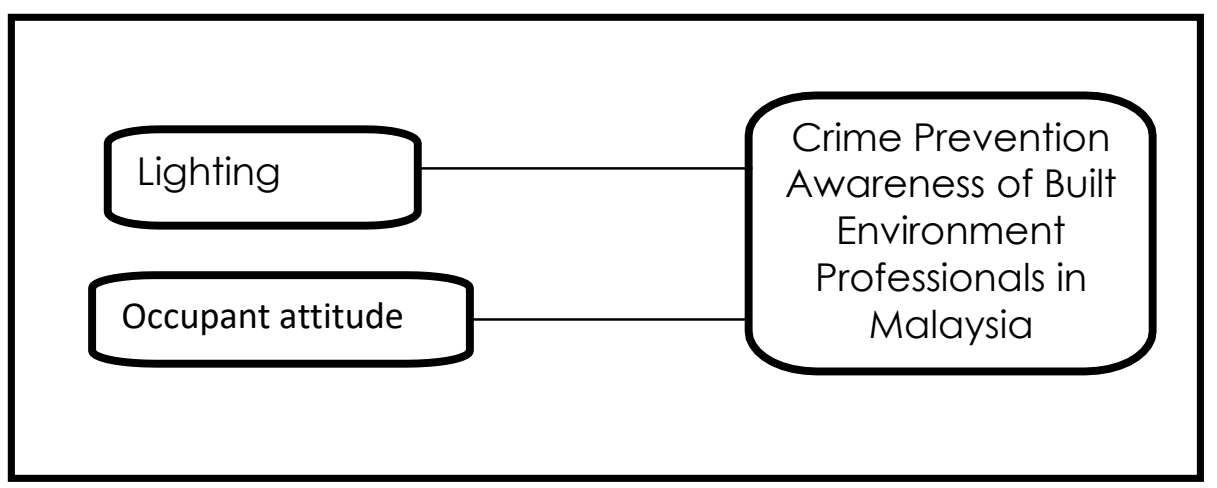


Figure 1 Crime Prevention Criteria Affecting Crime Prevention Awareness of Built Environment Professionals in Malaysia

\subsection{CONCLUSION}

This study's main findings are the lighting and occupant attitude significantly contribute to crime prevention that built environment professionals considered to implement in Malaysian housing. Other crime prevention criteria such as layout design, building design, parking, access and walkways, landscape and urban design elements, safety equipment, management and maintenance, and community were not significant. Furthermore, this study found that all the built environment professionals are currently working with the developers registered under the Real Estate and Housing Developers Association of Malaysia (REHDA).

\section{ACKNOWLEDGEMENT}

The FRGS grant fully supported this research. The authors gratefully acknowledge the Ministry of Higher Education (MOHE) and Universiti Sains Malaysia for their approved funds, making this critical research viable and effective.

\section{REFERENCES}

[1] Shafii, H., \& Miskam, N. (2011). Pembentukan penunjuk dan indeks kualiti hidup bagi mengukur kesejahteraan hidup masyarakat di Pekan Parit Raja, Johor.

[2] United Nations Development Programme. (, 2013). The Rise of The South: Human Progress in a Diverse World. Human Development Report, 2013. New York: UNDP.

[3] Robin, R. O. (2017). Kajian terhadap kos pembinaan rumah kos rendah di Sarawak (Doctoral dissertation, Universiti Tun Hussein Onn Malaysia).

[4] Sernau, S. (2009). Global problems: The search for equity, peace, and sustainability. Allyn \& Bacon.

[5] Jabatan Perangkaan Malaysia. (2016). Siaran Akhbar Unjuran Penduduk (Semakan Semula) Malaysia, 2010-2040. Pejabat Ketua Perangkawan Malaysia.

[6] Zulkepli, M. (2011). Pembangunan model penentuan keperluan perumahan. Kajian kes: Johor Bahru, Malaysia (Doctoral dissertation, Universiti Tun Hussein Onn Malaysia).

[7] Sukimin, S. (2008). Persepsi terhadap kualiti dan kepuasan perumahan dalam kalangan pemilik rumah kos rendah di Kota Kinabalu, Sabah, Malaysia (Doctoral dissertation, Universiti Putra Malaysia).

[8] Bujang, A. A., Zarin, H. A., \& Jumadi, N. (2010). The relationship between demographic factors and housing affordability. Malaysian Journal of Real Estate, 5(1), 49-58.

[9] Junaidi, A. B. (2015). Geopolitik dan program perumahan rakyat di Kuala Lumpur pasca pilihan raya umum ke-13/Junaidi Awang Besar (Doctoral dissertation, University of Malaya).

[10] Mustaffa, J. (2007). Aspek keselamatan awam dalam pembentukan bandar selamat di Malaysia: kajian kes Alor Star, Kedah (Doctoral dissertation, Universiti Sains Malaysia).

[11] Othman, N. A. (2007). Kriteria perancangan dalam pembangunan perumahan komuniti berpagar di kawasan Dewan Bandaraya Kuala Lumpur (Doctoral dissertation, Universiti Teknologi Malaysia).

[12] Johar, S. S., Ani, F., Hamzah, S., \& Halim, H. (2017). Tingkah laku devian dan perlakuan jenayah: cabaran kecenderungan negatif di sebalik kehidupan masa lalu dan kini.

[13] Jabatan Perancangan Bandar dan Desa. (2010). Bandar Selamat 2010 Safe City. Kementerian Perumahan dan Kerajaan Tempatan. Kuala Lumpur: Jabatan Perancangan Bandar dan Desa Semenanjung Malaysia.

[14] Latif, F. M., Nordin, N. A., \& Au-Yong, C. P. (2017). Rekabentuk bagi keselamatan bandar di Kuala Lumpur: Satu ulasan kritis (Urban design for a safe city: A critical review of Kuala Lumpur). GeografiaMalaysian Journal of Society and Space, 11(9).

[15] Newman, O. (1972). Defensible space (p., 264). New York: Macmillan.

[16] Pauzi, H. M. (2017). Konsistensi maltamat dan objektif Program Perumahan Kos Rendah dengan keperluan perumahan kumpulan sasar. The Malaysian Journal of Social Administration, 9(1), 87-106.

[17] Jabatan Perancangan Bandar dan Desa. (2011). Draf Garis Panduan Penerangan Tempat Letak Kenderaan. Kuala Lumpur: Jabatan Perancangan Bandar dan Desa Semenanjung Malaysia. 
[18] Smith, M. S. (1996). Crime prevention through environmental design in parking facilities. US Department of Justice, Office of Justice Programs, National Institute of Justice.

[19] Ali, N. E. (2006). Pembangunan komuniti di dalam perlaksanaan konsep bandar selamat: kajian kes: Bukit Jelutong Seksyen U8 Shah Alam, Selangor Darul Ehsan (Doctoral dissertation, Universiti Teknologi Malaysia).

[20] Jabatan Landskap Negara. (2008). Garis Panduan Landskap Negara (Edisi 2). Kementerian Wilayah Persekutuan: Jabatan Landskap Negara.

[21] Meinig, D. W. (1979). The beholding eye: Ten versions of the same scene. The interpretation of ordinary landscapes: Geographical essays, 33-48.

[22] Clarke, R. V. G. (2008). Improving street lighting to reduce crime in residential areas. US Department of Justice, Office of Community Oriented Policing Services.

[23] Zinalibdin, N., \& Lyndon, N. (2017). Makna rasa selamat komuniti Malaysia dalam Program Skim Rondaan Sukarela: Kajian kes KRT Taman Putera Jaya, Kota Kinabalu, Sabah (The meaning of safety in Malaysia's community development programmes: A case study of KRT Taman Putera Jaya, Kota Kinabalu, Sabah). Geografia-Malaysian Journal of Society and Space, 12(5).

[24] Yusoff, Y. M., Tawil, N. M., Hamzah, N., Abdullah, N. A. G., Musa, A. R., \& Bina, J. S. (2011). Tinjauan kesan fasiliti kediaman bertingkat terhadap amaun dana pengurusan. Journal of Design+Built, $32-40$.

[25] Jacobs, J. (2016). The death and life of great American cities. Vintage.

[26] Kreuger, L., \& Neuman, W. L. (2006). Social work research methods: qualitative and quantitative approaches: with Research Navigator. Pearson/Allyn and Bacon.

[27] Sekaran, U., \& Bougie, R. (2003). Research Methods For Business, A Skill Building Approach, John Willey \& Sons. Inc. New York.

[28] Bougie, R., \& Sekaran, U. (2009). Research methods for business: A skill-building approach. Hoboken.

[29] Fadzil, S. N. F. (2013). Faktor yang mempengaruhi permintaan penyewaan perumahan (Doctoral dissertation, Universiti Teknologi Malaysia).

[30] Leh, F. C. (2017). Pelancongan bandar dan isu keselamatan: Kajian kes pelancong antarabangsa Kuala Lumpur. Geografia-Malaysian Journal of Society and Space, 12(8). 